УДК 330.46:519.71

Вівчар О. І., д.е.Н., професор,

Vivchar O. Doctor of Economic Sciences, Professor https://orcid.org/0000-0001-9246-2226

\title{
РИЗИКИ ЛОГІСТИЧНОГО УПРАВЛІННЯ ЕКОНОМІЧНОЇ БЕЗПЕКИ ПІДПРИСМСТВ ТРАНСПОРТУ: ПРАКТИЧНІ КОНТЕКСТИ
}

\author{
Західноукраӥнський національний університет
}

\begin{abstract}
Проведено комплексне дослідження ризиків логістичного управління економічної безпеки підприємств транспорту в сучасних умовах. Встановлено, що ризик логістичного управління економічної безпеки підприємств транспорту - це сукупність економічних, організаційних і технічних дій, спрямованих на встановлення видів, факторів та джерел ризику, оцінку величини ризику, розроблення й реалізацію заходів щодо зниження його рівня й запобігання можливим негативним наслідкам i враховує фактори впливу зовнішнього середовища - конкурентів, постачальників, урядових рішень, суспільної думки, кон'юнктури, недостачі повноцінної релевантної інформації тощо. Відзначено, що основними функціями ризику є інноваційна, регулятивна, захисна, компенсаційна, соціально-економічна й аналітична.

Обгрунтовано, що ризики можуть бути визначені кількісним та якісним аналізом (правило мінімакс (критерій Севіджа); правило Гурвіца). Доведено, що система показників кількісної оцінки ризиків в системі економічної безпеки охоплює абсолютні величини (дисперсія, середньоквадратичне відхилення, семіваріація, семіквадратичне відхилення), відносні (ймовірність, коефіцієнт варіації, коефіцієнт ризику). Сформовано комплексне дослідження коефіцієнтом ризику логістичного управління економічної безпеки підприємств транспорту. Виокремлено основні методи регулювання ступеню ризику підприємств транспорту: уникнення ризику; компенсація ризику; прогнозування; моніторинг; збереження ризику; створення спеціальних резервних фондів; залучення зовнішніх джерел; передача ризику; хеджування; зниження ризику. На основі чого доведено, що метою зниження ризиків економічної безпеки підприємств транспорту можна вважати комплексну протидію потенційним та реальним загрозам, а також забезпечення високого потенціалу розвитку підприємств транспорту у майбутньому.
\end{abstract}

Ключові слова: управління ризиками, логістична стратегія, економічна безпека, підприємства транспорту, ремонт автошляхів.

\section{RISKS OF LOGISTICS MANAGEMENT OF ECONOMIC SAFETY TRANSPORT ENTERPRISES: PRACTICAL CONTEXTS}

\author{
Western Ukrainian National University
}

A comprehensive study of risks the logistics management of economic security transport enterprises in modern conditions. It is established that the risk of logistics management of economic security transport enterprises is a set of economic, organizational and technical actions aimed at identifying types, factors and sources of risk, risk assessment, development and implementation of measures to reduce its level and prevent possible negative consequences and take into account factors the influence of the external environment - competitors, suppliers, government decisions, public opinion, market conditions, lack of full relevant information, etc. It is noted that the main functions of risk are innovative, regulatory, protective, compensatory, socio-economic and analytical.

It is substantiated that risks can be determined by quantitative and qualitative analysis (minimax rule (Savage criterion; Hurwitz rule). It is proved that the system of indicators quantitative risk assessment in the system of economic security covers absolute values (variance, standard deviation, semi-variation, seven-square deviation), relative (probability, coefficient of variation, risk factor). A comprehensive study of risk factor the logistics management of economic security transport enterprises has been formed. The main methods of regulating the degree of risk transport enterprises are identified: risk avoidance; risk compensation; prognostication; monitoring; risk retention; creation of special reserve funds; involvement of external sources; risk transfer; hedging; risk reduction. On the basis of which it is proved that the purpose of reducing the risks of economic security of transport enterprises can be considered a comprehensive response to potential and real threats, as well as ensuring a high potential for development of transport enterprises in the future.

Key words: risk management, logistics strategy, economic security, transport enterprises, road repairs. 
Постановка проблеми у загальному вигляді i ïi зв'язок 3 важливими науковими та практичними завданнями. В сучасних трансформаційних умовах підприємств транспорту без ризику - неіснує. Слід відзначити, що ризик обов'язково має бути розрахований до максимально припустимої межі. 3 практичної точки зору ринкові оцінки є різноманітними. Важливо не боятися помилок у своїй ринковій діяльності, оскільки від них ніхто не застрахований, а головне - не повторювати помилок, постійно коригувати систему дій із позиції поліпшення дорожньо-ремонтних робіт.

Аналіз останніх досліджень, у яких започатковано вирішення проблеми. Дослідженню проблемним аспектам ризиків логістичного управління економічної безпеки підприємств транспорту у свій час розглядали Б. Андрушків, Л. Головкова, В. Захарченко, М. Єрмошенко, С. Крикавський, Л. Ларіна, М. Окландер, Г. ПастернакТаранушенко, С. Пирожкова, О. Тридіда, М. Флейчук, В. Франчук У. Щурко, В. Храпкіна.

Цілі статті. Метою статті є комплексне оцінювання типів ризику логістичного управління економічної безпеки підприємств транспорту в сучасних трансформаційних умовах та обгрунтування відповідної моделі.

Виклад основного матеріалу дослідження 3 повним обгрунтуванням отриманих наукових результатів. На основі проведених досліджень встановлено, що головною метою логістичного управління економічної безпеки - можливості для пом'якшення різких коливань функціонування підприємств транспорту, тому особливу увагу необхідно приділяти постійному вдосконаленню діяльності з управління ризиком. Управління ризиком в контексті логістичного управління підприємств транспорту - це процес прийняття рішень та здійснення заходів, спрямованих на забезпечення мінімально можливого ризику.

На нашу думку, ризик логістичного управління економічною безпекою підприємств транспорту, варто розуміти сукупність економічних, організаційних i технічних дій, спрямованих на встановлення видів, факторів та джерел ризику, оцінку величини ризику, розроблення й реалізацію заходів щодо зниження його рівня й запобігання можливим негативним наслідкам і враховує фактори впливу зовнішнього середовища - конкурентів, постачальників, урядових рішень, суспільної думки, кон'юнктури, недостачі повноцінної релевантної інформації тощо. Для наочного зображення на рис. 1 подано типову схему процесу управління ризиками [2, с. 168].

Так, встановлено, що функція ризику економічної безпеки - стимулювання пошуку шляхів нетрадиційного розв'язання проблем, що виникають перед підприємством транспорту. Більшість підприємств транспорту досягають успіху, стають конкурентоспроможними на базі інноваційної діяльності, пов'язаної з ризиком. Дана модель чітко відображає основну мету логістичного управління ризиками економічної безпеки - їх мінімізація з метою уникнення або часткового зменшення можливих фінансових, матеріальних та інших втрат від дії ризиків.

В економічній літературі виділяють такі функції ризику, як: інноваційна, регулятивна, захисна, компенсаційна, соціально-економічна й аналітична. Інноваційна функція ризику - стимулювання пошуку шляхів нетрадиційного розв'язання проблем, що виникають перед суб' єктом - підприємствами транспорту. Підприємства транспорту досягають успіху, стають конкурентоспроможними на основі інноваційної діяльності, пов'язаної з ризиком. 


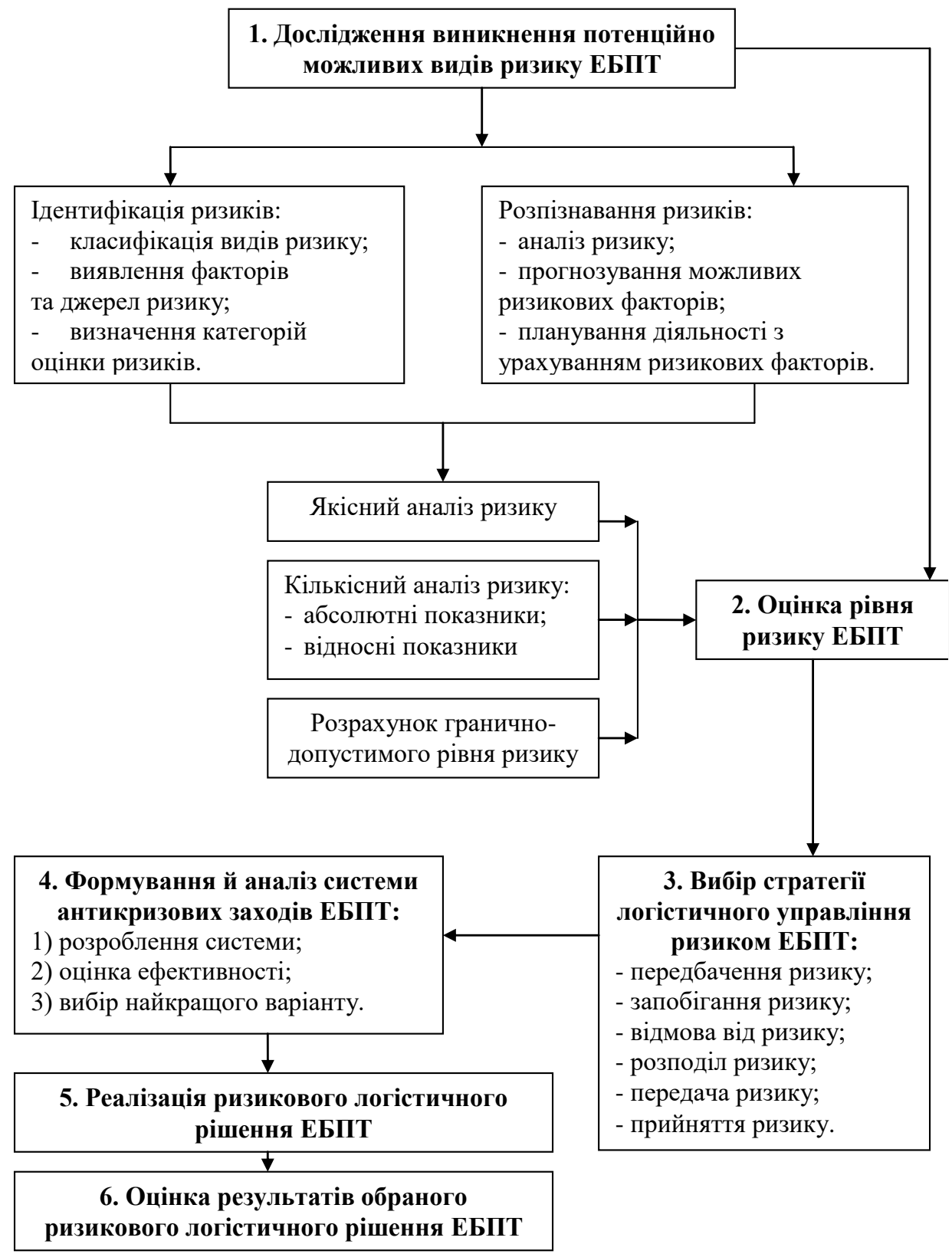

Рис. 1. Модель ризиків логістичного управління економічної безпеки підприємств транспорту (ЕБПТ)

[авторська розробка]

Обов’язкова умова дієвої логістичної системи управління економічною безпекою - дотримання певних принципів, основними з яких є:

- усвідомлення прийняття ризиків;

- чітке формулювання мети логістичного управління ризиками та можливість впливу на ті характеристики ризиків, які сприяють досягненню цілі;

- об'єктивність, достовірність, повнота і надійність інформації;

- охоплення управлінням ризиком усіх горизонтальних i вертикальних ієрархічних рівнів підприємств транспорту, органічний зв'язок усіх управлінських елементів підприємницького ризику (системний підхід);

- незалежність логістичного управління окремими ризиками;

- мінімізація спектру можливих ризиків та ступінь їхнього впливу;

- швидка реакція підприємств транспорту на внутрішні та зовнішні зміни, що 
полегшують реалізацію ризику;

- врахування фактора часу в логістичному управлінні ризиками;

- мінімізація витрат на організацію та логістичне управління ризиками;

- інноваційний підхід до логістичного управління ризиками [7].

Аналіз рівня ризику логістичного управління економічної безпеки найвідповідальніший і методично складний етап процесу логістичного управління, від якості проведення якого залежить ефективність ризик-менеджменту взагалі, який передбачає кількісну та якісну оцінки. Доцільність прийняття конкретного господарського рішення, що містить певні ризики, може бути визначена кількісним та якісним аналізом цих ризиків. Система показників кількісної оцінки ризиків в системі економічної безпеки охоплює абсолютні величини (дисперсія, середньоквадратичне відхилення, семіваріація, семіквадратичне відхилення), відносні (ймовірність, коефіцієнт варіації, коефіцієнт ризику) [3]. Сформуємо дослідження розрахунку за коефіцієнтом ризику:

$$
K_{R}=S S_{V A R}^{-} / S S_{V A R}^{+},
$$

Результати розрахунків подано в табл. 1.

Таблиця 1

Коефіцієнт ризику економічної безпеки підприємств транспорту

\begin{tabular}{|c|c|c|c|c|c|c|}
\hline \multirow{2}{*}{$\begin{array}{c}\text { Лтргістичні } \\
\text { стогегі екомічної безпеки, }\end{array}$} & \multicolumn{5}{|c|}{ Логістичні витрати на ремонт автошляхів } & \multirow{2}{*}{ KR } \\
\cline { 2 - 6 }$S i$ & 1 & 2 & 3 & 4 & 5 & \\
\hline$S 1$ & 17 & 5 & 24 & 10 & 4 & 2,06 \\
\hline$S 2$ & 11 & 20 & 14 & 32 & 46 & 0,34 \\
\hline$S 3$ & 35 & 5 & 3 & 37 & 2 & 6,42 \\
\hline$S 4$ & 15 & 14 & 10 & 30 & 6 & 0,32 \\
\hline$S 5$ & 17 & 23 & 20 & 9 & 12 & 0,59 \\
\hline$S 6$ & 19 & 4 & 16 & 2 & 1 & 2,21 \\
\hline
\end{tabular}

Чим менший коефіцієнт ризику $\left(K_{R}\right)$, тим менший ризик. За цим показником найвигіднішою $є$ четверта логістична стратегія ремонту автошляхів.

Інтервальна оцінка ефективності кожної логістичної стратегії та визначення типу ризику економічної безпеки кожної з них. Для іï визначення необхідно розрахувати граничну похибку, що $є$ абсолютним показником інтегральної оцінки ризику [6]. Результати розрахунків подано в табл. 2.

Таблиця 2

Граничні похибки економічної безпеки підприємств транспорту

\begin{tabular}{|c|c|c|c|c|c|c|}
\hline \multirow{2}{*}{$\begin{array}{c}\text { Логістичні } \\
\text { стратегії економічної } \\
\text { безпеки, } S i\end{array}$} & \multicolumn{5}{|c|}{ Логістичні витрати на ремонт } & \multirow{2}{*}{$\Delta i$} \\
\cline { 2 - 6 } автошляхів підприємств транспорту & \multicolumn{2}{|c|}{} \\
\hline$S 1$ & 1 & 2 & 3 & 4 & 5 & 15,61 \\
\hline$S 2$ & 17 & 5 & 24 & 10 & 4 & 25,53 \\
\hline$S 3$ & 11 & 20 & 14 & 32 & 46 & 38,86 \\
\hline$S 4$ & 35 & 5 & 3 & 37 & 2 & 13,42 \\
\hline$S 5$ & 15 & 14 & 10 & 30 & 6 & 10,08 \\
\hline$S 6$ & 17 & 23 & 20 & 9 & 12 & 20,43 \\
\hline
\end{tabular}

$$
\Delta_{i}=t \times \lambda_{k r u t} \times \delta_{i}
$$


де $t$ - критерій Стьюдента (таблична величина); $\lambda$ - рівень значущості, або ймовірність, з якою відхиляється рівень граничної похибки.

Додамо граничну похибку до середньої ефективності (математичного сподівання) й отримаємо максимально можливий рівень ефективності зі заданою ймовірністю: $a_{i} \max =M_{i}+\Delta_{i}$. У результаті віднімання матимемо мінімально можливе значення очікуваної ефективності: $a_{i} \min =M_{i}-\Delta_{i}$. Чим менше значення граничної похибки (граничного відхилення), тим безпечніша й надійніша логістична стратегія фінансовоекономічної безпеки. Такою є п'ята логістична стратегія. Результати розрахунків подано в табл. 3.

Таблиця 3

Максимально та мінімально можливий рівень ефективності економічної безпеки підприємств транспорту

\begin{tabular}{|c|c|c|c|c|c|c|c|}
\hline \multirow{2}{*}{$\begin{array}{c}\text { Логістичні } \\
\begin{array}{c}\text { стратегії економічної } \\
\text { безпеки, } S i\end{array}\end{array}$} & \multicolumn{5}{|c|}{$\begin{array}{c}\text { Логістичні витрати на ремонт } \\
\text { автошляхів підприємств }\end{array}$} & \multirow{2}{*}{$a_{i}$ max } & \multirow{2}{*}{$a_{i}$ min } \\
\cline { 2 - 7 } & 1 & 2 & 3 & 4 & 5 & & \\
\hline$S 1$ & 17 & 5 & 24 & 10 & 4 & 29,59 & $-1,63$ \\
\hline$S 2$ & 11 & 20 & 14 & 32 & 46 & 41,73 & $-9,33$ \\
\hline$S 3$ & 35 & 5 & 3 & 37 & 2 & 65,37 & $-12,35$ \\
\hline$S 4$ & 15 & 14 & 10 & 30 & 6 & 28,74 & 1,90 \\
\hline$S 5$ & 17 & 23 & 20 & 9 & 12 & 27,42 & 7,26 \\
\hline$S 6$ & 19 & 4 & 16 & 2 & 1 & 34,32 & $-6,54$ \\
\hline
\end{tabular}

За табл. 3 можемо проаналізувати зміни граничних інтервалів ефективності логістичних стратегій економічної безпеки вибору ділянки автошляхів:

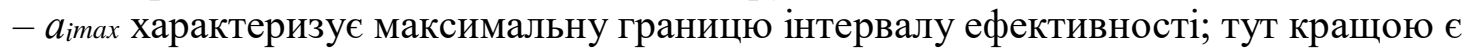
третя логістична стратегія економічної безпеки;

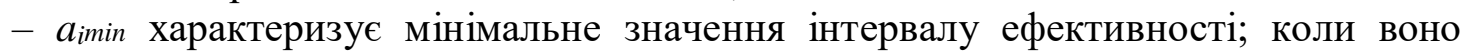
від'ємне, тоді можемо бачити розмір втрат; із урахуванням з цих умов вигіднішою $є$ п'ята логістична стратегія, завдяки своїй незбитковості та найбільшому додатному значенню [4].

Визначимо ризик на основі розмаху варіації:

$$
R_{i V A R}=a_{i} \max -a_{i} \min ,
$$

Результати розрахунків подано в табл. 4.

Чим більше розмах варіації, тим більший ризик притаманний логістичній стратегії. Отже, п’ята логістична стратегія є найменш ризикованою.

Таблиця 4

Розмах варіації логістичної стратегії економічної безпеки підприємств транспорту

\begin{tabular}{|c|c|c|c|c|c|c|}
\hline \multirow{2}{*}{$\begin{array}{c}\text { Логістичні } \\
\text { стратегії економічної } \\
\text { безпеки, } S i\end{array}$} & \multicolumn{5}{|c|}{ Логістичні витрати на ремонт } & \multirow{2}{*}{ Ri VAR } \\
\cline { 2 - 6 } & 1 & 2 & 3 & 4 & 5 & \\
\hline$S 1$ & 17 & 5 & 24 & 10 & 4 & 31,22 \\
\hline$S 2$ & 11 & 20 & 14 & 32 & 46 & 51,05 \\
\hline$S 3$ & 35 & 5 & 3 & 37 & 2 & 77,72 \\
\hline$S 4$ & 15 & 14 & 10 & 30 & 6 & 26,85 \\
\hline$S 5$ & 17 & 23 & 20 & 9 & 12 & 20,16 \\
\hline$S 6$ & 19 & 4 & 16 & 2 & 1 & 40,86 \\
\hline
\end{tabular}


Для того, щоб простежити динаміку стратегій економічної безпеки підприємств транспорту, зобразимо графічно три останніх показники (рис. 2).

Розмах варіаціï ( $\left.\mathbf{R}_{\mathrm{iVAR}}\right)$

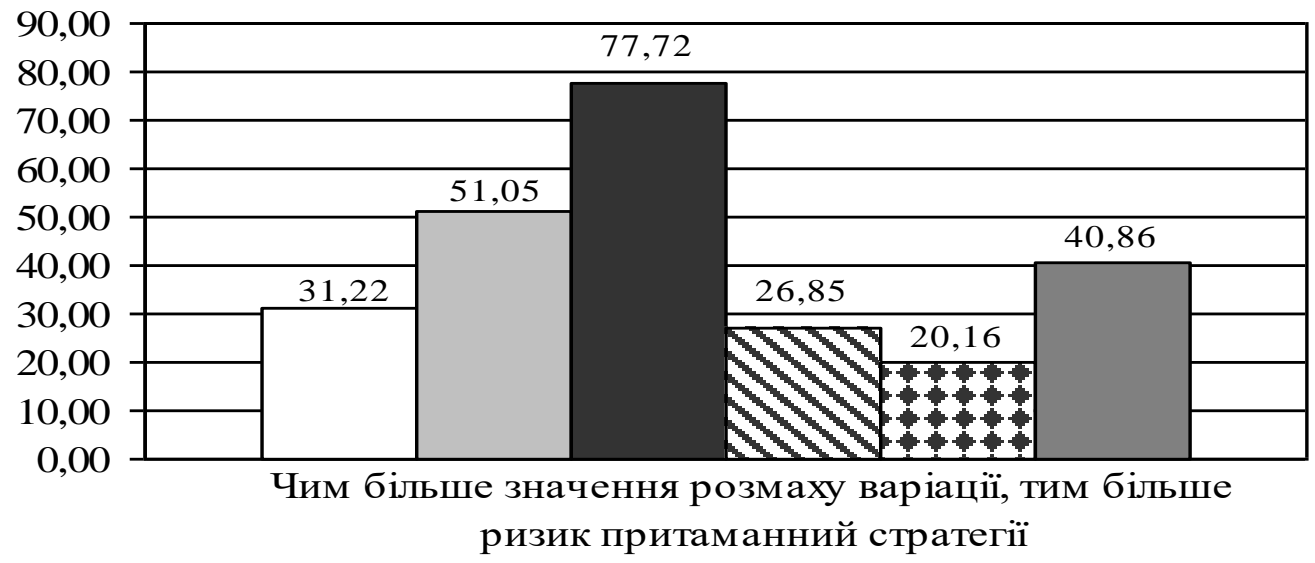

Рис. 2. Динаміка розмаху варіації логістичної стратегії економічної безпеки підприємств транспорту

Встановимо тип ризику через підрахунок відсотка втрат для кожної логістичної стратегії (табл. 5).

Таблиця 5

Тип ризику економічної безпеки підприємств транспорту

\begin{tabular}{|c|c|c|c|c|c|c|c|}
\hline \multirow{2}{*}{$\begin{array}{c}\text { Логістичні } \\
\text { стратегії економічної } \\
\text { безпеки, } S i\end{array}$} & \multicolumn{5}{|c|}{$\begin{array}{c}\text { Логістичні витрати на ремонт } \\
\text { автошляхів підприємств } \\
\text { транспорту }\end{array}$} & \multirow[t]{2}{*}{ Втрати, \% } & \multirow[t]{2}{*}{ Тип ризику } \\
\hline & 1 & 2 & 3 & 4 & 5 & & \\
\hline S1 & 17 & 5 & 24 & 10 & 4 & $-11,68$ & Допустимий \\
\hline$S 2$ & 11 & 20 & 14 & 32 & 46 & $-57,56$ & Критичний \\
\hline S3 & 35 & 5 & 3 & 37 & 2 & $-46,58$ & Допустимий \\
\hline S4 & 15 & 14 & 10 & 30 & 6 & 12,37 & Допустимий \\
\hline S5 & 17 & 23 & 20 & 9 & 12 & 41,86 & Допустимий \\
\hline S6 & 19 & 4 & 16 & 2 & 1 & $-47,1$ & Допустимий \\
\hline
\end{tabular}

Отже, логістична стратегія S5 $\epsilon$ найвигіднішою за всіма показниками. Оцінювання господарського ризику передбачає необхідність побудови кривої ризику підприємств транспорту. Це надзвичайно складне завдання, тому на практиці доводиться обмежуватися спрощеними підходами, оцінюючи ризик за одним або кількома показниками. Прийняття остаточного рішення щодо здійснення конкретного вибору ділянки автошляхів потребує визначення граничного рівня господарського ризику. Можна орієнтуватися на такі показники, як 0,1, 0,01 та 0,001 відповідно для допустимого, критичного і катастрофічного ризиків [5].

Якісний аналіз оцінки ризику має на меті визначити чинники й зони ризику та ідентифікувати можливі ризики. Виникнення кожного окремого виду ризику підприємств транспорту зумовлюють специфічні чинники. У рамках діяльності підприємств транспорту може бути використана така класифікація зон ризику: безризикова зона економічної безпеки, зона допустимого ризику економічної безпеки, зона критичного ризику економічної безпеки, зона катастрофічного ризику економічної безпеки [1]. Доцільність прийняття конкретного логістичного рішення економічної безпеки підприємств транспорту, що містить певні ризики, може бути визначена якісним аналізом ризиків (табл. 6). 
Характеристика критеріїв якісного аналізу ризиків

\begin{tabular}{|c|c|}
\hline $\begin{array}{c}\text { Правило } \\
\text { (критерій) }\end{array}$ & Характеристика \\
\hline $\begin{array}{l}\text { Правило } \\
\text { мінімакс } \\
\text { (критерій } \\
\text { Севіджа) } \\
\text { Правило } \\
\text { Гурвіца }\end{array}$ & $\begin{array}{l}\text { Мінімакс орієнтований на мінімізацію жалю з приводу втраченого прибутку і } \\
\text { допускає розумний ризик заради отримання додаткового прибутку. } \\
\text { Розрахунок критерію складається з чотирьох етапів: } \\
\text { Знаходимо кращий результат кожної графи (максимум аіј). } \\
\text { Визначаємо відхилення від кращого результату кожної окремої графи, тобто тахі } \\
\text { аij - аіј. Отримані результати створять матрицю ризику, тому що їі елементи - це } \\
\text { недоотриманий прибуток від невдало прийнятих рішень, допущених через } \\
\text { помилкову оцінку можливості реакції ринку. } \\
\text { Для кожного рядка матриці жалю знаходимо максимальне значення. } \\
\text { Обираємо рішення, за якого максимальний жаль буде меншим, аніж за інших } \\
\text { рішень. } \\
\text { Критерій використовують тоді, коли необхідно обрати стратегію захисту об'єкта } \\
\text { від надто великих утрат. Використання критерію Севіджа доцільним тільки за } \\
\text { умови достатньої фінансової стабільності підприємства, коли є впевненість, що } \\
\text { випадковий збиток не призведе до повного краху }\end{array}$ \\
\hline $\begin{array}{l}\text { Правило } \\
\text { Гурвіца }\end{array}$ & $\begin{array}{l}\text { Відповідно до цього правила максімакс і максимін сполучаються зв'язуванням } \\
\text { максимуму мінімальних значень альтернатив. Це правило називають ще правилом } \\
\text { оптимізму-песимізму. Оптимальну альтернативу можна розрахувати за формулою: } \\
\mathrm{a}^{*}=\alpha \text { maxјаіј }+(1-\alpha) \text { minjaij, де } \alpha-\text { коефіцієнт оптимізму, } \alpha=1 . .0 \text { (коли } \alpha=1 \text {, } \\
\text { альтернативу вибирають за правилом максімакс, якщо } \alpha=0-\text { па правилом } \\
\text { максимін). } \\
\text { В основу правила покладено використання критерію Гурвіца. Застосовуючи } \\
\text { правило Гурвіца, враховують істотнішу інформацію, чіза ніж при використанні } \\
\text { правил максимін і максімакс }\end{array}$ \\
\hline
\end{tabular}

Вибір методів та інструментів регулювання ступеню ризику підприємств транспорту - важливий етап процесу логістичного управління системи економічної безпеки. Основними напрямами впливу та методами регулювання ступеню ризику є: уникнення ризику (відмова від ненадійних партнерів, постачальників; відмова від прийняття ризикованих проєктів, рішень); компенсація ризику (стратегічне планування діяльності; прогнозування зовнішньої економічної ситуації; моніторинг економічного і правового середовища; активний цілеспрямований маркетинг); збереження ризику (відмова від будь-яких дій, спрямованих на компенсацію збитку; створення спеціальних резервних фондів у натуральній або грошовій формі (фондів самострахування або фондів ризику); залучення зовнішніх джерел (отримання кредитів та позик, державних дотацій для компенсації збитків та відновлення виробництва); передача ризику (страхування; передача ризиків через укладання договорів факторингу, поручительства; передача ризику шляхом укладання біржових угод (хеджування); зниження ризику (диверсифікація; здобуття додаткової інформації; лімітування) [8].

Висновки. Прорезюмувавши вище описане, слід відзначити, що метою зниження ризиків економічної безпеки підприємств транспорту можна вважати комплексну протидію потенційним та реальним загрозам, усунення та мінімізація яких гарантують суб'єкту господарювання стале та максимально ефективне функціонування у мінливих умовах зовнішнього та внутрішнього середовища на даний момент часу, а також забезпечення високого потенціалу розвитку підприємств транспорту у майбутньому.

\section{Список бібліографічного опису}

1. Андрушків Б. М. Економічна та майнова безпека підприємства та підприємництва. Антирейдерство: монографія. Тернопіль: Тернограф, 2012. 456 с.

2. Вівчар О. І. Парадигма і наукова база логістичного управління. Соціально-економічні проблеми і держава. Вип. 1(4). 2011. C. 166-173. URT: http://sepd.tntu.edu.ua/images/stories/pdf/2011/11zmfblm.pdf.

3. Вівчар О. І. Логістичні аспекти фінансово-економічної безпеки підприємств з ремонту й експлуатації автошляхів: монографія. Тернопіль, Астон, 2013. 232 с.

4. Гейдт А. А. Разработка методов планирования воспроизводства сети автомобильных дорог промышленных узлов. 
Автореферат к-та техн. Наук. - Омск, 2004.

5. Григорук П. М., Хрущ Н. А. Методологічні засади моделювання системи забезпечення фінансово-економічної безпеки в умовах невизначеності і багатомірності ринкового середовища. Науковий вісник Мукачівського державного університету. 2017. С. 198-204.

6. Жалина О. М. Повышение ровности покрытий автомобильных дорог по условию обеспечения комфорта, удобства и безопасности движения (с использованием теории риска). Наука и техника в дорожной отрасли. 2004. № 2. С. $27-$ 29.

7. Пономарьова Ю. В. Логістика: Навчальний посібник. К.: Центр навчальної літератури, 2005. 328 с.

8. Vivchar O., Kolesnikov A. Peculiarities of assessment technologies usage in the management of financial and economic security of enterprises. Business Economics. Issue 4 (2), (October). Volume 51. "Palgrave Macmillan Ltd.", 2016. Pages 393398.

\section{References}

1. Andrushkiv, B M. (2012) Ekonomichna ta mainova bezpeka pidpryiemstva ta pidpryiemnytstva. Antyreiderstvo [Economic and property security of enterprise and entrepreneurship. Anti-crap]. Ternopil: Ternohraf. [in Ukrainian].

2. Vivchar, O. I. (2011) Paradyhma i naukova baza lohistychnoho upravlinnia. Sotsialno-ekonomichni problemy i derzhava [Paradigm and scientific base of logistic management. Socio-economic problems and the state]. 1(4). 166-173. URT: http://sepd.tntu.edu.ua/images/stories/pdf/2011/11zmfblm.pdf [in Ukrainian].

3. Vivchar, O. I. (2013) Lohistychni aspekty finansovo-ekonomichnoi bezpeky pidpryiemstv z remontu y ekspluatatsii avtoshliakhiv: monohrafiia [Logistic aspects of financial and economic safety of enterprises for repair and operation of highways] Ternopil, Aston, 232 [in Ukrainian].

4. Geydt, A. A. (2004) Razrabotka metodov planirovaniya vosproizvodstva seti avtomobilnykh dorog promyshlennykh uzlov [Development of methods of planning of reproduction of the network of highways of industrial sites] Avtoreferat. Omsk. [in Ukrainian].

5. Hryhoruk, P. M., \& Khrushch, H. A. (2017) Metodolohichni zasady modeliuvannia systemy zabezpechennia finansovoekonomichnoi bezpeky v umovakh nevyznachenosti i bahatomirnosti rynkovoho seredovyshcha [Methodological principles of modeling the system of providing financial and economic security in the conditions of uncertainty and multidimensionality of the market environment]. Naukovyi visnyk Mukachivskoho derzhavnoho universytetu - Scientific Bulletin of the Mukachevo State University, 1, 204-198 [in Ukrainian].

6. Zhalina, O. M. (2004) Povyshenie rovnosti pokrytiy avtomobilnykh dorog po usloviyu obespecheniya komforta, udobstva i bezopasnosti dvizheniya (s ispolzovaniem teorii riska) [Improvement of the level of road coverings on the condition of providing comfort, convenience and safety of movement (using the theory of risk)]. Nauka i tekhnika v dorozhnoy otrasliScience and technology in the road industry. № 2. 27-29 [in Ukrainian].

7. Ponomarova, Yu. V. (2005) Lohistyka: Navchalnyi posibnyk [Logistics]. K.: Tsentr navchalnoi literatury. 328. [in Ukrainian].

6. Vivchar O., \& Kolesnikov A. (2016) Peculiarities of assessment technologies usage in the management of financial and economic security of enterprises. Business Economics. Issue 4 (2), (October). Volume 51. "Palgrave Macmillan Ltd.”. Pages 393-398.

Дата подання публікації 23.09.2020 р. 